\title{
Severe pre-eclampsia in the gynecology and obstetrics department of the CHR of Koudougou: epidemiological, clinical, therapeutic and prognostic aspects
}

\section{Nebnomyidboumbou Norbert Wenceslas Djiguemde ${ }^{1 *}$, Martin Lankoande ${ }^{2}$, Samira L. Pitroipa ${ }^{3}$, Estelle Ouedraogo ${ }^{3}$, N. S. Madeleine Dabire ${ }^{1}$, Blandine Thieba Bonane ${ }^{3}$}

\author{
${ }^{1}$ Department of Obstetrics and Gynecology, ${ }^{2}$ Department of Resuscitation Anesthesiologgy, CHR Koudougou, \\ Boulkiemde, Koudougou, Burkina Faso \\ ${ }^{3}$ Department of Gynecology, CHU YO, Kadiogo, Ouagadougou, Burkina Faso
}

Received: 06 March 2021

Revised: 07 May 2021

Accepted: 10 May 2021

\section{*Correspondence:}

Dr. Nebnomyidboumbou Norbert Wenceslas Djiguemde,

E-mail: norbertdjig@yahoo

Copyright: ( ) the author(s), publisher and licensee Medip Academy. This is an open-access article distributed under the terms of the Creative Commons Attribution Non-Commercial License, which permits unrestricted non-commercial use, distribution, and reproduction in any medium, provided the original work is properly cited.

\section{ABSTRACT}

Background: To study the epidemiological, clinical, therapeutic and prognostic aspects of severe pre-eclampsia in the gynecology and obstetrics department of the CHR of Koudougou.

Methods: descriptive cross-sectional study with prospective collection from January 1 to December 31, 2018. The variables studied focused on clinical socio-demographic characteristics, treatment and prognosis. The women admitted to the department and meeting the criteria for severe pre-eclampsia were included, more than 20 weeks of amenorrhea with an increase in blood pressure, presence of albumin in the urine and signs of clinical or biological seriousness.

Results: Severe pre-eclampsia represented $2.3 \%$ of admissions and 3\% of deliveries. The clinical profile was that of a young housewife $(51.2 \%)$, married $(72.4 \%)$, nulliparous $(44.1 \%)$ with a pregnancy in the 3rd trimester. Symptoms were dominated by headache $(53.5 \%)$ and diastolic blood pressure $\geq 110 \mathrm{mmHg}(66.9 \%)$, with albuminuria greater than two crosses and hyperuricemia. Magnesium sulfate and clonidine were the most commonly prescribed anticonvulsant and antihypertensive drug, respectively. Cesarean section was performed in $53 \%$ of cases.

Maternal complications were noted in $57.5 \%$ of cases without death. However, the fetus took a heavy toll with $50.7 \%$ morbidity and $14 \%$ perinatal mortality.

Conclusions: Severe pre-eclampsia is responsible for heavy morbidity - perinatal mortality. Improving maternal and fetal prognosis will require compliance with treatment protocols and greater accessibility of care at all levels of the health pyramid.

Keywords: Severe pre-eclampsia, Prognosis, Treatment, Regional hospital center of Koudougou, Burkina Faso

\section{INTRODUCTION}

Along with severe bleeding, infections and illegal induced abortion, high blood pressure is one of the leading causes of maternal mortality. It is ranked third with an incrimination in $14 \%$ of maternal deaths. ${ }^{1}$ In hypertensive syndromes associated with pregnancy, preeclampsia has an incidence and mortality that make it a major public health issue in developing countries. ${ }^{2}$ In Africa, studies conducted on severe pre-eclampsia and eclampsia in Morocco and Benin have shown maternal 
mortality of 1.6 to $6.8 \%$ and early neonatal mortality varying between 42 and 176 deaths per 1000 live births. ${ }^{3}$

In Burkina, studies report maternal mortality of 1.08 to $2.1 \%$ and early neonatal mortality varying between 57 and 270 deaths per 1000 live births. ${ }^{4,5}$ Thus, we deemed it necessary to conduct a study in a regional hospital center to determine the epidemiological, clinical, therapeutic and prognostic aspects of severe pre-eclampsia in order to modestly contribute to improving management and prognosis.

\section{METHODS}

The study took place at the Gynecology-Obstetrics department of the regional hospital center (CHR) of Koudougou between January 1 and December 31, 2018 in Koudougou, capital of the province of Boulkiemdé with a total regional population of the center west is estimated at 1,598,159 inhabitants for the year 2018 (INSD 2016 projection). ${ }^{6}$ This was a descriptive crosssectional study with prospective data collection and concerned women admitted urgently to the gynecologyobstetrics department of CHR Koudougou for severe preeclampsia.

\section{Inclusion criteria}

Inclusion criteria for current study were ; all the women admitted to the delivery room and to hospitalization in the gynecology-obstetrics department of the Koudougou CHR during the study period and meeting the criteria for severe pre-eclampsia.

\section{Exclusion criteria}

Inclusion criterion for current study was; all women who presented with eclampsia in the service.

Data was collected using an individual sheet. We carried out an interview and a documentary review. The data sources come from medical records, referral and evacuation records, patient monitoring and treatment records, childbirth and hospitalization records, and operative report records. The data collected was entered using a microcomputer and analyzed with Sphinx Plus 2 version 5.1.0.2 and SPSS version 22 software. The anonymity and confidentiality of the data collected was respected. The results of the study were made available to stakeholders in the field of maternal and child health.

\section{Statistical analysis}

The several epidemiological and clinical variables were studied: age, socio-professional status, spouse's occupation, provenance, marital status, mode of admission, reasons for referral, medical history, gynecological and obstetrical history, gestational age, the number of fetuses, variables related to the clinical profile of the parturient, variables related to the circumstances of childbirth, variables related to the maternal and fetal prognosis

\section{RESULTS}

Total 5484 women were admitted and 4233 deliveries were performed with 127 cases of severe pre-eclampsia, or $2.3 \%$ of emergency admissions and $3 \%$ of deliveries in the gynecology-obstetrics department. The distribution of patients by month of admission is shown in (Figure 1). The average age is $26.75 \pm 6.6$ years with extremes of 15 years and 42 years.

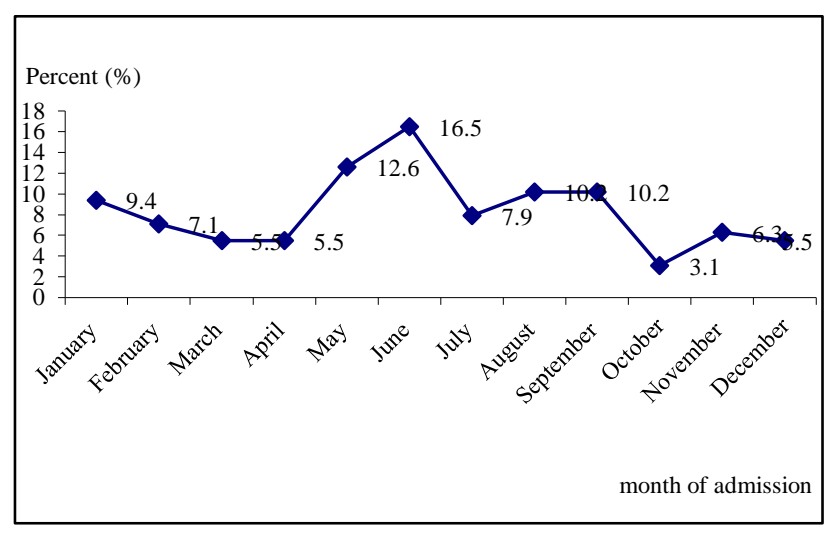

Figure 1: Distribution of patients by month of admission $(\mathrm{n}=127)$.

\section{Antecedents}

Some patients had an associated pathological history. Chronic hypertension was the antecedent found in $10.2 \%$ (13 cases), preeclampsia and diabetes $0.8 \%$ ( 1 case), the scarred uterus $4.7 \%$ (6 cases), appendectomy $1.6 \%$ (2 cases) and no history $79.5 \%$ (101 cases).

\section{Admission data}

We have $80.3 \%$ from other structures, of which 63 or $61.7 \%$ came from CSPS, $38.3 \%$ from medical centers. Hypertension was the cause in $80.3 \%$. The diagnosis is suggested in the ante-partum department in $45.7 \%$, in intrapartum in $50.4 \%$ and in immediate postpartum less than 3 hours in $3.9 \%$. The functional signs were headache $53.5 \%$, vertigo $21.3 \%$, visual blurring $6.3 \%$ ( 8 cases) and abdominal pain in a bar in $4.7 \%$. They were not found in $43.3 \%$. The mean admission blood pressure was $164.4 \pm$ $16.2 \mathrm{mmHg}$ for SBP with extremes of 130 and 230 $\mathrm{mmHg}$ and $108.9 \pm 9.5 \mathrm{mmHg}$ for DBP with extremes of 90 and $150 \mathrm{mmHg}$. Among our patients, 88 or $69.3 \%$ had SBP $\geq 160 \mathrm{mmHg}$ and 85 or $66.9 \%$ had DBP $\geq 110$ $\mathrm{mmHg}$.

\section{Ultrasound data}

Fetal ultrasound was normal in $72.1 \%$ of cases and the main abnormalities encountered were MFIU, IUGR and acute fetal distress. 
Table 1: Sociodemographic characteristics.

\begin{tabular}{|ll|}
\hline Parameters & N $(\%)$ \\
\hline Maternal age (years) & \\
\hline $15-19$ & $23(18.1)$ \\
\hline $20-24$ & $28(22)$ \\
\hline $25-29$ & $31(24.4)$ \\
\hline $30-34$ & $23(18.1)$ \\
\hline $35-40$ & $19(15)$ \\
\hline$>40$ & $3(2.4)$ \\
\hline Profession & \\
\hline Student & $15(11.8)$ \\
\hline College Student & $12(09.4)$ \\
\hline Civil servant & $22(17.3)$ \\
\hline Housewives & $5(51.2)$ \\
\hline Informal sector & $13(10.3)$ \\
\hline Marital status & \\
\hline Married & $92(72.4)$ \\
\hline Single & $17(13.4)$ \\
\hline Cohabitation & $18(14.2)$ \\
\hline Residence (\%) & 66.9 \\
\hline Other cities in the health region & 11.8 \\
\hline Urban & 21.3 \\
\hline rural area & $50(41)$ \\
\hline Number of prenatal consultations & $72(59)$ \\
\hline $1-3$ & \\
\hline $4-6$ & \\
\hline
\end{tabular}

Table 2: Circumstances of admission to the service.

\begin{tabular}{|lll|}
\hline Admission circumstances $(\mathbf{n = 1 2 7})$ & $\mathbf{N}$ & $\%$ \\
\hline Reason for admission & & \\
\hline HTA & 102 & 80.3 \\
\hline Edemas & 11 & 08.7 \\
\hline Headache & 04 & 03.1 \\
\hline Dizziness & 02 & 01.6 \\
\hline SFA & 05 & 03.9 \\
\hline HRP & 03 & 02.4 \\
\hline Anemia & 03 & 02.4 \\
\hline DAP/CU & 09 & 07.1 \\
\hline Dyspnea & 01 & 00.8 \\
\hline Abdominal pain & 01 & 00.8 \\
\hline Palpitations & 01 & 00.8 \\
\hline RPM & 05 & 03.9 \\
\hline Vicious presentation & 04 & 03.1 \\
\hline Fetal macrosomia & 03 & 02.4 \\
\hline MAP & 02 & 01.6 \\
\hline Loss of consciousness & 03 & 02.4 \\
\hline Oligoanuria & 04 & 03.1 \\
\hline
\end{tabular}

\section{Job characteristics}

On admission, they were in labor in $68.9 \%$ of cases and this labor was spontaneous in $75 \%$ of cases. The patients admitted in the immediate postpartum had given birth vaginally. As for pregnant and parturient women (122), a conservative treatment of pregnancy was administered in 07 cases, i.e. 5.7\%. In 115 cases the delivery was performed vaginally in 54 cases and by cesarean section in 61 cases.

Table 3: Distribution of patients based on data from the general examination on admission.

\begin{tabular}{|lll|}
\hline General admission exam $(\mathbf{n = 1 2 7})$ & $\mathbf{N}$ & $\%$ \\
\hline Condition & & \\
\hline Well & 117 & 92.2 \\
\hline Good enough & 10 & 7.8 \\
\hline Bad & 00 & 0.0 \\
\hline State of consciousness & & \\
\hline Claire & 125 & 98.4 \\
\hline Obsessed & 02 & 1.6 \\
\hline Conjunctiva & & \\
\hline Colorful & 95 & 74.8 \\
\hline Little colored & 25 & 19.7 \\
\hline Pale & 07 & 5.5 \\
\hline Edemas & & \\
\hline No & 56 & 44.1 \\
\hline IMO & 70 & 55.1 \\
\hline Generalized & 01 & 0.8 \\
\hline
\end{tabular}

Table 4: Distribution of patients according to obstetric data on admission.

\begin{tabular}{|lll|}
\hline Obstetric data on admission $(\mathbf{n = 1 2 7})$ & $\mathbf{N}$ & $\%$ \\
\hline Gesture & & \\
\hline Primigest & 58 & 45.7 \\
\hline Paucigeste & 44 & 34.6 \\
\hline Multigest & 23 & 18.1 \\
\hline Large multigest & 02 & 01.6 \\
\hline Parity & & \\
\hline Nulliparous & 56 & 44.1 \\
\hline Primiparous & 19 & 15.0 \\
\hline Pauciparous & 30 & 23.6 \\
\hline Multiparous & 21 & 16.5 \\
\hline Large multipare & 01 & 00.8 \\
\hline Gestational age (AS) & & \\
\hline $20-22$ & 00 & 00.00 \\
\hline $22-28$ & 04 & 03.3 \\
\hline $28-37$ & 33 & 27.0 \\
\hline $37-42$ & 85 & 69.7 \\
\hline Pregnancy type & & \\
\hline Monofetal & 108 & 88.5 \\
\hline Twin & 14 & 11.5 \\
\hline & & \\
\hline
\end{tabular}

\section{Characteristics of the fetus at birth}

The distribution of newborns according to their characteristics at birth is shown in (Table 8). 
Table 5: Distribution of patients according to biological data on admission.

\begin{tabular}{|c|c|c|}
\hline $\begin{array}{l}\text { Biological data on } \\
\text { admission }(n=127)\end{array}$ & Frequency & $\%$ \\
\hline \multicolumn{3}{|l|}{ Platelets $\left(/ \mathrm{mm}^{3}\right)$} \\
\hline$<150000$ & 11 & 08.7 \\
\hline $150000-350000$ & 105 & 82.7 \\
\hline$>350000$ & 11 & 08.7 \\
\hline \multicolumn{3}{|l|}{ Creatinine $(\mu \mathrm{mol} / \mathrm{l})$} \\
\hline$<100$ & 101 & 80.8 \\
\hline$\geq 100$ & 24 & 19.2 \\
\hline \multicolumn{3}{|c|}{ Uricemia $(\mu \mathrm{mol} / \mathrm{l})(\mathrm{N}=45)$} \\
\hline$<350$ & 21 & 46.6 \\
\hline $350-450$ & 13 & 28.8 \\
\hline $450-600$ & 09 & 00.2 \\
\hline$>600$ & 02 & 04.4 \\
\hline \multicolumn{3}{|l|}{ Albuminuria } \\
\hline 2 croix & 59 & 43.3 \\
\hline 3 croix & 62 & 48.8 \\
\hline 4 croix & 06 & 04.7 \\
\hline \multicolumn{3}{|l|}{ ASAT (UI/I) (N=76) } \\
\hline $0-35$ & 55 & 72.4 \\
\hline $35-70$ & 16 & 21.1 \\
\hline$>70$ & 05 & 06.6 \\
\hline \multicolumn{3}{|l|}{ ALAT (UI/I) (N=76) } \\
\hline $0-40$ & 68 & 89.5 \\
\hline $40-80$ & 03 & 03.9 \\
\hline$>80$ & 05 & 06.6 \\
\hline \multicolumn{3}{|l|}{$\mathrm{TP}(\%)(\mathrm{N}=08)$} \\
\hline$<70$ & 03 & 37.5 \\
\hline $70-100$ & 05 & 62.5 \\
\hline$>100$ & 00 & 00.0 \\
\hline
\end{tabular}

Table 6: Work characteristics.

\begin{tabular}{|lll|}
\hline Job characteristics & Frequency & $\%$ \\
\hline Work in progress $(\mathbf{N = 1 2 2})$ & & \\
\hline No & 38 & 31.1 \\
\hline Yes & 84 & 68.9 \\
\hline Fashion (N=84) & & \\
\hline Spontaneous & 63 & 75.0 \\
\hline Artificial triggering & 21 & 25.0 \\
\hline Directed work & 72 & 85.7 \\
\hline
\end{tabular}

\section{Treatment}

All our patients benefited from antihypertensive and anticonvulsant treatment and general resuscitation measures with mainly volume expansion in $97.6 \%$ of cases. Anti-hemorrhagic treatment with etamsylate or tranxenamic acid was administered to 3 patients.

\section{Maternal prognosis}

Response to treatment; normalization of blood pressure was obtained in $66.9 \%$ of cases and $4.7 \%$ of our patients progressed to eclampsia despite preventive treatment of seizures.

Table 7: Characteristics of newborns and stillborns.

\begin{tabular}{|lcc|}
\hline Characteristics $(\mathbf{n = 1 2 9})$ & N & $\%$ \\
\hline Term & & \\
\hline Born at term & 96 & 74.4 \\
\hline Pre-term & 33 & 25.6 \\
\hline Weight $(\mathbf{g})$ & & \\
\hline $500-1500$ & 07 & 05.4 \\
\hline $1500-2500$ & 45 & 34.8 \\
\hline $2500-3500$ & 70 & 54.3 \\
\hline $3500-4000$ & 06 & 04.8 \\
\hline$\geq 4000$ and more & 01 & 00.7 \\
\hline Vitality at birth & & \\
\hline Yes & 120 & 93.0 \\
\hline No & 09 & 07.0 \\
\hline
\end{tabular}

\section{Maternal complications and deaths}

In current study $57.5 \%$ of women presented with complications. Acute renal failure was found in $18.9 \%$ of them. We have not recorded any maternal deaths

\section{Perinatal prognosis}

The patients admitted after a recent childbirth (5 in number), the newborns were taken care of in the delivery room. A satisfactory assessment of their clinical condition on arrival allowed referral to pediatrics for advice, but all returned to the mother. Conservative treatment was offered in 7 cases due to prematurity and the absence of any biological sign requiring urgent extraction

\section{Perinatal morbidity}

No morbidity was noted in patients, i.e. $49.3 \%$. Perinatal morbidity was low birth weight type in $45.2 \%$, prematurity $24.3 \%$, fetal distress $18.4 \%$ and neonatal jaundice $0.7 \%$.

\section{Fetal and neonatal mortality}

Study involved 129 births, the 7 pregnancies being progressive at the end of the study period. We recorded 09 stillbirths out of 129 births, i.e. a stillbirth rate of 70 deaths per 1000 births.

The number of deaths in the early neonatal period was 09 out of 120 live births, resulting in an early neonatal mortality of 75 deaths per 1000 live births. Perinatal mortality was 140 deaths per 1000 births, or 18 fetuses and newborns died out of 129 births. 
Table 8: Summary of support.

\begin{tabular}{|c|c|c|}
\hline Data $(n=127)$ & $\mathbf{N}$ & $\%$ \\
\hline \multicolumn{3}{|l|}{ Intensive care } \\
\hline Left lateral decubitus & 127 & 100.0 \\
\hline Peripheral venous route & 127 & 100.0 \\
\hline Volume expansion & 124 & 97.6 \\
\hline Urinary catheterization & 127 & 100.0 \\
\hline Oxygen & 06 & 04.7 \\
\hline Guedel cannula & 06 & 04.7 \\
\hline Red blood cell base & 09 & 07.1 \\
\hline Fresh frozen plasma & 03 & 02.4 \\
\hline \multicolumn{3}{|l|}{ Antihypertensives } \\
\hline Nicardipine & 06 & 04.7 \\
\hline Clonidine & 121 & 95.3 \\
\hline$\alpha$ Methyl-dopa & 127 & 100.0 \\
\hline Nifedipine & 14 & 11.0 \\
\hline Enalapril & 01 & 00.8 \\
\hline Amlodipine & 10 & 07.9 \\
\hline Indapamide & 01 & 00.8 \\
\hline \multicolumn{3}{|l|}{ Anticonvulsants } \\
\hline Diazepam+magnesium sulfate & 06 & 04.7 \\
\hline Magnesium sulfate & 121 & 95.3 \\
\hline \multicolumn{3}{|l|}{ Anxiolytic } \\
\hline No & 118 & 92.9 \\
\hline Bromazepam & 07 & 05.5 \\
\hline Hydroxyzine & 02 & 01.6 \\
\hline \multicolumn{3}{|l|}{ Obstetrical treatment } \\
\hline Conservative treatment & 07 & 05.7 \\
\hline Non-conservative treatment & 115 & 94.3 \\
\hline \multicolumn{3}{|l|}{ Delivery route } \\
\hline High & 61 & 53.0 \\
\hline Low & 54 & 47.0 \\
\hline \multicolumn{3}{|l|}{ Pediatric transfer } \\
\hline Yes & 42 & 35.0 \\
\hline No & 78 & 65.0 \\
\hline
\end{tabular}

Table 9: Maternal complications ( $\mathrm{n}=127)$.

\begin{tabular}{|lll|}
\hline Maternal complications & N & $\%$ \\
\hline Any & 54 & 42.5 \\
\hline HELLP syndrome & 05 & 04.0 \\
\hline Acute renal failure & 24 & 18.9 \\
\hline Coagulation disorder & 03 & 2.4 \\
\hline Acute Lung Edema & 01 & 00.8 \\
\hline Retention of placental debris & 11 & 08.6 \\
\hline Retro Placental Hematoma & 03 & 02.4 \\
\hline Anemia & 20 & 15.7 \\
\hline Eclampsia & 06 & 04.7 \\
\hline
\end{tabular}

Table 10: Discharge method and length of hospitalization.

\begin{tabular}{|lll|}
\hline $\begin{array}{l}\text { Discharge and duration of } \\
\text { hospitalization }(\mathbf{n = 1 2 7})\end{array}$ & $\mathbf{N}$ & $\%$ \\
\hline Output mode & & \\
\hline Output without MV & 85 & 66.9 \\
\hline Output with HTA & 42 & 33.1 \\
\hline Cardiology consultation & 127 & 100 \\
\hline Nephrology consultation & 03 & 02.4 \\
\hline Duration of hospitalization (days) & & \\
\hline $0-1$ & 3 & 02.4 \\
\hline $2-3$ & 38 & 29.9 \\
\hline $4-5$ & 31 & 24.4 \\
\hline$>5$ & 55 & 43.3 \\
\hline
\end{tabular}

\section{DISCUSSION}

Current study experienced limitations and constraints in relation to stockouts of certain reagents during hospitalization. Despite these limitations and constraints, we achieved these results which we compared to the data in the literature.

The frequency of severe preeclampsia was 3\% of deliveries. Our rates are close to those obtained by Tchaou et al. in 2012 in Benin which in its series noted $4.7 \% .^{3}$

The mean age was $26.7 \pm 6.9$ years with extremes of 15 years and 42 years. The most represented age group was 25 to 29 years old and $40.1 \%$ of our patients were under 25 years old. Our results are similar to those of Tchaou et al in Benin in 2012 who respectively regained an average age of 26.4 years with $46.8 \%$ of patients under 25 years old. ${ }^{3}$ This young age of our patients corroborates the data in the literature. Indeed, authors such as Richet and Beaufils, as well as Lamazou and Salama stipulate that severe pre-eclampsia has a maximum incidence before 25 years. ${ }^{7,8}$ Housewives were the most represented with a rate of $51.2 \%$.

Tchaou et al in Benin in 2012 found in its series a frequency markedly lower than ours with $31 \%$ of housewives. ${ }^{3}$ Cultural and economic differences could explain this lack of similarity of results, coastal women seeking more autonomy and also having more possibilities of self-employment compared to women in landlocked countries like Burkina Faso. The young age of our study population and the extent of unemployment in our countries could be related to this high proportion of housewives in our series. Most of our population, 72.4\%, was married. Our results are superior to those of Nirina et al who reported $38.7 \%$ of married women in their studies. ${ }^{9}$ Despite the young age of our study population, the majority of them find themselves in the status of married women, probably due to early marriage encouraged by African tradition. $78.7 \%$ had an urban residence with $66.9 \%$ residing in the city of Koudougou. 
This high proportion of city dwellers could be explained by the fact that our study setting is a regional referral hospital receiving patients from other health structures in the city. We found a predominance of severe preeclampsia during the month of June with $16.5 \%$ of cases. Nirina et al also obtained in their series an oscillating curve with a plateau, shifted in time compared to our peak, going from September to October. ${ }^{9}$ Our results could be explained by the high number of deliveries in June. Humidity could also be implicated, thus corroborating the data in the literature which places humidity as a risk factor for preeclampsia. ${ }^{10}$

Pregnancy was monitored irregularly (01 to 03 ANC) in $41 \%$ and regularly in $59 \%$ of patients with a number of ANC consistent with WHO recommendations, which sets the minimum number at $04 .^{11}$ Indeed, the reproductive health awareness campaigns carried out by associative structures and the ministry of health could explain the improvement in the figures on pregnancy monitoring compared to previous years. We found a history of chronic arterial hypertension (10.2\%) and a history of preeclampsia $(0.8 \%)$. Hypertension was detected in $21.3 \%$ of cases during pregnancy follow-up. Our results are different from those of Tchaou et al. who noted in the history $3.9 \%$ of chronic arterial hypertension, $4.8 \%$ of preeclampsia. $^{3}$ Our results could be explained by the improvement of the equipment of health centers involved in reproductive health and the increase in the number of these centers allowing better monitoring of pregnancies and screening with early management of pathologies.

In current study, $85 \%$ of our patients were admitted for signs directly related to arterial hypertension (high blood pressure, headache, dizziness). Headache $53.5 \%$ and dizziness $21.3 \%$ of cases were the major functional signs. Our results could be explained by the fact that these signs testify to the aggravation of the hypertensive pathology consequently appearing at the stage of severe preeclampsia. We identified $55.1 \%$ of patients admitted with edema of the lower limbs (IMO) and $0.8 \%$ of cases with generalized edema, resulting in a total of $55.9 \%$ of edema cases.

Our results are lower than those of Tchaou et al which reported $62.1 \%$ of OMI versus $9.7 \%$ of generalized edema. ${ }^{3}$ Indeed, edema is a classic but optional clinical sign of preeclampsia. Often physiological during pregnancy, edema, when associated with severe preeclampsia, is characterized by its sudden onset or rapid and significant increase, accompanied by rapid weight gain. ${ }^{12}$

High blood pressure is the first warning sign and appears to be a predictor of poor maternal and fetal prognosis if diastolic blood pressure is greater than or equal to 110 mmHg. ${ }^{13}$ Tchaou et al on the other hand, they found higher frequencies, namely $90.3 \%$ for patients with SBP $\geq 160 \mathrm{mmHg}$ and $98.1 \%$ for those with DBP $\geq 110$ $\mathrm{mmHg} .^{3}$

\section{Convulsions}

In our series, $4.7 \%$ of patients presented their inaugural seizure on admission or during hospitalization. The difference in our results with those of the above authors could be explained by the predominance of the nonconvulsive form of toxemia of pregnancy. Part of the explanation could also come from the fact that almost all of our patients benefited from treatment with magnesium sulfate during hospitalization.

Primigest and nulliparas are the most common in our series with $45.7 \%$ and $44.1 \%$ respectively. Our results are similar to those of Tchaou et al who found mostly nulliparas in their studies with $40.8 \% .^{3}$ This difference is also noted in comparison with the results of Nirina et al who found multiparas to be the most exposed group, representing $53.7 \%$ of their patients. ${ }^{9}$ Poor recognition of paternal antigens by the maternal organism in nulliparas, thus promoting poor tolerance of pregnancy, could explain the high proportion of these in our study. Our results corroborate the data in the literature which cites nulliparity as a factor favoring pre-eclampsia. ${ }^{13}$

The most represented gestational age group was that of 37 WA (completed) to 42 WA (not completed) with $69.7 \%$ of patients. Our results are close to those of Chaoui et al who identified $80.83 \%$ of patients with a gestational age exceeding 36 weeks. ${ }^{14}$ Our results support the inflammatory hypothesis which states that the inflammatory process, responsible for pre-eclampsia when exaggerated, peaks in the third trimester of pregnancy. ${ }^{15,16}$

\section{Biological data}

Albuminuria; in our series, albuminuria was massive (greater than or equal to 3 crosses) in $48.8 \%$ of cases. Our results support the importance of albuminuria in women with severe preeclampsia. It constitutes an element of gravity when it is greater than or equal to three crosses. The existence of massive proteinuria correlates with the severity of renal impairment. ${ }^{17-19}$

Creatinine and azotemia; a mean creatinine level of $81.7 \pm 36.9 \mu \mathrm{mol} / \mathrm{l}$ with extremes of 16.50 and $315 \mu \mathrm{mol} / \mathrm{l}$. We found $19.2 \%$ of cases of hyper-creatinine and hyperazotemia in $37 \%$ of cases. Hyperazotemia and hyper creatinine levels indicate kidney damage. They are most often a reflection of functional renal failure in severe preeclampsia. This could be explained by a decrease in filtration and plasma flow following true or relative hypovolaemia. ${ }^{17,20,21}$

Uricemia; impaired tubular function results in decreased clearance of uric acid responsible for hyper uricemia. An assay of the blood level of uric acid in our patients revealed a mean uricemia of $341.9 \pm 145.4 \mu \mathrm{mol} / 1$ with extremes of 104.50 and $710 \mu \mathrm{mol} / \mathrm{l}$. This hyper-uricemia, found in our patients with a level $\geq 350 \mu \mathrm{mol} / 1$ (34.4\%), 
indicates renal tubular damage and is correlated with placental ischemia as well as hypovolemiaand requires fetal extraction of 'emergency. ${ }^{20}$

Liver function: In our series we identified $27.7 \%$ of high ASAT rate (AST $>35 \mathrm{IU} / \mathrm{l})$ and $6.6 \%$ of ASAT $>105 \mathrm{IU} / \mathrm{l}$ (AST $>03$ times normal). Elevation of hepatic transaminases is one of the biological signs of severe preeclampsia and is part of Hellp syndrome when there is also severe hemolysis and thrombocytopenia. ${ }^{22,23}$

\section{Circumstances of childbirth}

Mode of admission; In our study $66.9 \%$ of the women were evacuated. Tchaou et al reported rates similar to ours, namely $66.9 \%$ evacuations. ${ }^{3}$ Evacuations help to reduce maternal-fetal morbidity and mortality linked to this pathology.

Job characteristics; Labor was spontaneous for $75 \%$ of them. The presence of labor could have an impact on the prognosis, especially fetal.

\section{Therapeutic data}

Resuscitation; All our patients benefited from general resuscitation measures with volume expansion (97.6\%), revival of diuresis with furosemide $(0.8 \%)$ of cases, oxygen therapy $(4.7 \%)$, an intake of blood derivatives, in particular red blood cells $(7.1 \%)$ and fresh frozen plasma (3.9\%). Tchaou et al. noted higher rates than ours with $21.1 \%$ of cases having received a blood derivative. ${ }^{3}$

Antihypertensive treatment; The use of antihypertensive drugs is justified in view of the major risk of stroke, especially when the blood pressure levels are very high. However, care must be taken to achieve a gradual reduction in blood pressure levels which are harmful to both the fetus and the mother. ${ }^{7,8,24}$ In our series, $100 \%$ of the patients benefited from an antihypertensive treatment and is superior to that found by Tchaou et al with $93.20 \% .^{3}$

The antihypertensive treatment included injectable clonidine (95.3\%), $\alpha$ methyl-dopa tablet (100\%) and injectable nicardipine $(4.7 \%)$, which are secondarily combined with each other and/or with other antihypertensive drugs. namely nifedipine tablet, amlodipine tablet and enalapril tablet. Our results are different from those of other authors. Indeed, Tchaou et al. found clonidine in $67.9 \%$, nicardipine in $25.2 \%$ of cases. $^{3}$ Our rates could be explained by the fact that treatment protocols are different depending on the country and the availability of antihypertensive drugs. The treatment protocol at the CHR in Koudougou includes a therapeutic regimen consisting of injectable clonidine one ampoule every 4 hours and injectable nicardipine $2 \mathrm{ml}$ every 30 minutes.
Anticonvulsants; in our series, $100 \%$ of patients benefited from magnesium sulfate. Getaneh and Kumbi in Ethiopia also administered in $100 \%$ of cases. ${ }^{25}$ Despite the preventive treatment instituted, $4.7 \%$ of patients presented seizures while Getaneh and Kumbi in Ethiopia reported no cases of seizures. ${ }^{25}$ Some authors are unanimous on the efficacy of magnesium sulfate in the prevention and onset of seizures. ${ }^{20,26}$ Our cases of eclampsia despite preventive treatment could be explained by non-compliance with treatment or by rupture of the product at the time of administration.

Obstetrical treatment; The delivery was by the upper route in $53 \%$ of cases. Since the fetal and maternal prognosis is threatened in the majority of our patients and uterine evacuation being the only curative treatment for severe pre-eclampsia, cesarean section has been most often used for maternal and/or fetal rescue. ${ }^{13}$ The vaginal route option is performed if maternal, fetal, and local conditions permit.

\section{Maternal prognosis}

Response to treatment; the response to treatment showed normalization of blood pressure at the outlet $(66.9 \%)$ and arrest of seizures in $100 \%$ of eclampsic patients. The goal of treatment was to normalize blood pressure before discharge and all of our births benefited from a follow-up appointment with the cardiologist.

Maternal morbidity; we identified $57.5 \%$ of women with complications. The main complications were renal failure (18.9\%), anemia (14.9\%) Hellp syndrome $(13.4 \%)$ and retro-placental hematoma $(10.3 \%)$. Our results are superior to that of Tchaou et al. which identified $7.5 \%$ of complicated cases with mainly eclampsia (30\%) and similar for renal failure $(20 \%) .^{3}$ The delay in consultation in health centers could explain this high rate because most of our patients were complicated cases on admission.

Maternal mortality; during the study, we did not record any maternal deaths. The method of recruiting cases on admission justifies our results. Also, our cases of eclampsia during hospitalization benefited from early management with a team of specialists.

\section{Perinatal prognosis}

Perinatal morbidity; we identified $49.3 \%$ of cases of perinatal morbidity. Complications were dominated by low birth weight $(38.2 \%)$, prematurity $(24.3 \%)$, acute fetal distress $(11.8 \%)$ and neonatal distress $(6.6 \%)$. This high morbidity rate is linked to the fact that in severe preeclampsia follows prematurity. ${ }^{3,13}$

Fetal and neonatal mortality; Stillbirth was 70 deaths per 1000 births, early neonatal mortality 75 deaths per 1000 live births $(7.5 \%)$ and perinatal mortality 140 deaths per 1000 births (14\%). Our rates are lower than those of 
some authors. Tchaou et al reported $25.4 \%$ in utero fetal death and $17.6 \%$ early neonatal death. ${ }^{3}$ Also, Kumari et al reported higher rates than ours at $13 \%$ intrauterine death, $10 \%$ early neonatal mortality and $23 \%$ perinatal mortality. ${ }^{27}$ The fetal and neonatal mortalities, relatively low compared to those of the other studies, could be explained by the fact that our patients benefited from a delivery in a hospital environment with neonatal resuscitation and multidisciplinary care available.

\section{CONCLUSION}

Severe preeclampsia is responsible for heavy perinatal morbidity and mortality at the Koudougou CHR. The response to protocol treatment showed normalization of blood pressure at discharge. The mean age was $26.7 \pm 6.9$ years, $10.2 \%$ history of chronic hypertension, $0.8 \%$ history of preeclampsia, and hypertension was discovered during pregnancy in $21.3 \%$. Improving maternal and fetal prognosis will require compliance with treatment protocols at all levels of the health pyramid.

\section{Funding: No funding sources}

Conflict of interest: None declared

Ethical approval: The study was approved by the Institutional Ethics Committee

\section{REFERENCES}

1. Say L, Chou D, Gemmill A, Tunçalp Ö, Moller AB, Daniels J, Gülmezoglu AM, Temmerman M, Alkema L. Global causes of maternal death: a WHO systematic analysis. Lancet Glob Health. 2014;2(6): e323-33.

2. Raphael V, Levasseur JE. EncyclMédChir. Emergency Med. 2007;25:45-9.

3. Tchaou BA, Salifou K, Hounkponou FM, Hountovo S, Chobli M. Management of severe preeclampsia in the university hospital of Parakou (Benin). RAMUR. 2012;17(2):22-9.

4. National Institute of Statistics and Demography of Burkina Faso. 2006 general population and housing census. Ouagadougou. Available at: http://ghdx. healthdata.org/organizations/national-institutestatistics-and-demography-burkina-faso. Accessed on 20 January 2021.

5. Burkina Faso Ministry of Health. Statistical yearbook 2010. Ouagadougou: general directorate for health information and statistics. Available at: https://www.un-spider.org/sites/default/files/Burkina Faso_Health_Care_Development_Support_Project_C entre_-_East_and_North_Regions_Appraisal_Report. pdf. Accessed on 20 January 2021.

6. Burkina Faso Ministry of Economy and Finance. Statistical yearbook 2014. Ouagadougou: National Institute of Statistics and Demography. Available at the URL: http://www.insd.bf/n/contenu/pub_periodi ques/annuaire_stat/Annuaire_stat_nationaux_BF/Ann uaire_stat_2014.pdf. Accessed on 20 January 2021.
7. Gabriel RM. Beaufils: Nephrology. France : Editions Marketing; 1988:287-92.

8. Lamazou F, Salama S. Obstetric gynecology. 2nd ed. Netherlands: Elsevier; 2010:119-26.

9. Harioly NOJ, Rasolonjatovo TY, Andrianirina M, Randriambololona DMA, Ranoaritiana DB, Andrianjatovo JJ, et al. Epidemiological profile of preeclampsia and eclampsia admitted to the intensive care unit of adults in the Befelatanana maternity hospital. Rev D'Anes-Réanim and Med d'Urg. 2009; 1(3):22-4.

10. Lankoandé J, Toure B, Ouédraogo A, Ouédraogo CMR, Ouattara P, Bonané B, et al. Eclampsia in the maternity ward of the Yalgado Ouédraogo National Hospital in Ouagadougou (Burkina Faso), epidemiological, clinical and evolutionary aspects. Med Afr Noire. 1998;45:399-402.

11. Prevention, treatment of eclampsia and preeclampsia: summary of recommendations. Available at: http: //whqlibdoc.who.int/hq/2011/WHO_RHR_11.30_eng. pdf. Accessed on 20 January 2021.

12. Beaufils M. Pregnancy-related hypertension. Rev Med Interne. 2002;23(11):927-38.

13. Haddad B, Beaufils M, Bavoux F. Management of preeclampsia. In: French obstetricians. Paris: Vigot Editions; 2001;5:34.

14. Chaoui A, Tyane M, Belouali R. Management of preeclampsia and eclampsia. 2nd national consensus conference Morocco. Marrakech. 2002;19:20-1.

15. MacKay AP, Berg CJ, Atrash HK. Pregnancy-related mortality from preeclampsia and eclampsia. Obstet Gynecol. 2001;97(4):533-8.

16. Merviel P, Challier JC, Foidart JM, Uzan S. Precis of obstetric gynecology; implantation and placentation: physiologies, pathologies, and treatments. France: Elseviers Masson; 2000:372.

17. Sbai H, Khatouf M, Smail L, Bouazzaoui H, Essatara Y, Harrandou M, et al. Management of severe preeclampsia and 1 eclampsia in surgical intensive care. About 97 cases. J Magh Réa Méd Urg. 2008;15: 172-5.

18. Rizk NW, Kalassian KG, Gilligan T, Druzin MI, Daniel NL. Obstetric complications in pulmonary and critical care medicine. Chest. 1996;110(3):791-808.

19. Schiff E, Friedman SA, Kao L, Sibai BM. The importance of urinary excretion during conservative management of severe preeclampsia. Am J Obstet Gynecol. 1996;175:1313-6.

20. Landau R, Irion O. Data on physiopathology and recommendation for management (preeclampsia from physiopathology to treatment). Rev Méd Suisse Angiolol Hemostasis. 2005;1(4):290-5.

21. Haddad B, Barton JR, Livingston JC, Chahine R, Sibai BM. HELLP syndrome versus severe preeclampsia: onset at $<28$ weeks gestation. Am J Obstet Gynecol. 2000;183(6):1475-9.

22. Moignet C, Diemunsch P, Pottecher T. Anesthesia, resuscitation and preeclampsia. Obstet Gynecol. 1998;91(6):909-16. 
23. Sibai BM. Diagnosis, controversies and management of the syndrome of hemolysis, elevated liver enzymes, and low platelet count. Obstet Gynecol. 2004;103(5): 981-91.

24. Courbiere B, Carcopino X. Obstetric Gynecology: National Classifying Tests (ECN). France: Vernazobres-Grego; 2007;51-62.

25. Getaneh W, Kumbi S. Use of magnesium sulfate in preeclampsia and eclampsia in teaching hospitals in Addis Ababa: a practice audit. Ethiopian Med J. 2010;48(2):157-64.

26. Magpie trial follow-up study collaborative group. The Magpie trial: a randomized trial comparing magnesium sulfate with placebo for pre-eclampsia. Outcome for women at 2 years. BJOG. 2007;114:3009.
27. Kumari A, Chakrawarty A, Singh A, Singh R. Maternal and fetal complications and their association with proteinuria in a tertiary care hospital in a developing country. J Pregnancy. 2014; 2014:6-27.

Cite this article as: Djiguemde NNW, Lankoande M, Pitroipa SL, Ouedraogo E, Dabire NSM, et al. Severe pre-eclampsia in the gynecology and obstetrics department of the CHR of Koudougou: epidemiological, clinical, therapeutic and prognostic aspects. Int J Reprod Contracept Obstet Gynecol 2021;10:2148-56. 